\title{
Novel methods for studying normal and disordered erythropoiesis
}

\author{
LIU Jing ${ }^{1}, \mathrm{HAN} \mathrm{Xu}^{1} \&$ AN XiuLi ${ }^{2 *}$ \\ ${ }^{1}$ State Key Laboratory of Medical Genetics \& School of Life Sciences, Central South University, Changsha 410078, China; \\ ${ }^{2}$ College of Life Sciences, Zhengzhou University, Zhengzhou 450001, China
}

Received August 12, 2015; accepted September 27, 2015; published online November 19, 2015

\begin{abstract}
Erythropoiesis is a process during which multipotential hematopoietic stem cells proliferate, differentiate and eventually form mature erythrocytes. Interestingly, unlike most cell types, an important feature of erythropoiesis is that following each mitosis the daughter cells are morphologically and functionally different from the parent cell from which they are derived, demonstrating the need to study erythropoiesis in a stage-specific manner. This has been impossible until recently due to lack of methods for isolating erythroid cells at each distinct developmental stage. This review summarizes recent advances in the development of methods for isolating both murine and human erythroid cells and their applications. These methods provide powerful means for studying normal and impaired erythropoiesis associated with hematological disorders.
\end{abstract}

erythropoiesis, erythroid progenitors, erythroblast, surface markers, transcriptional profile

Citation: $\quad$ Liu J, Han X, An XL. Novel methods for studying normal and disordered erythropoiesis. Sci China Life Sci, 2015, 58: 1270-1275, doi: $10.1007 / \mathrm{s} 11427-015-4971-8$

As a part of the hematopoiesis, erythropoiesis includes the whole process in which the multipotential hematopoietic stem cells develop into mature red cells within the hematopoietic microenvironment [1]. Although this process is a continuum, it can be functionally divided into two major steps namely early stage erythropoiesis and terminal erythroid differentiation. During early stage erythropoiesis, HSCs are committed to early stage erythroid progenitor burst-forming unit-erythroid cells (BFU-E) which further differentiate to late stage erythroid progenitor colonyforming unit-erythroid (CFU-E) cells. During terminal erythroid differentiation, CFU-E cells undergo 4-5 mitoses to sequentially become proerythroblast (Pro-E), basophilic erythroblast (Baso-E), polychromatic erythroblast (Poly-E) and orthochromatic erythroblasts (Ortho-E) which expel nucleus to generate enucleated reticulocytes.

Disordered or ineffective erythropoiesis is a feature of a large number of human hematological disorders. These in-

*Corresponding author (email: anxl@zzu.edu.cn) clude Cooley's anemia [2-5], congenital dyserythropoietic anemia's (CDA) [6-8], Diamond-Blackfan Anemia (DBA) [9,10], malarial anemia [11-13] and various bone marrow failure syndromes such as myelodysplastic syndromes (MDS) [14-16]. It is very likely that more human diseases associated with disordered erythropoiesis will be uncovered in the future. Thus, a detailed understanding of the process of erythropoiesis is of both biological and clinical significance.

Furthermore, it is interesting to note that dyserythropoiesis manifests itself at different developmental stages in these disorders with defects in erythroid progenitors observed primarily in DBA [17,18], cytokinesis/enucleation defects in congenital dyserythropoietic anemia type I-III (CDA I-III) [19-22], and apoptosis of terminally differentiating cells in Cooley's anemia and MDS [23-27]. These findings suggest that different dyserythropoietic disorders are driven by perturbations in normal gene expression patterns at distinct developmental stages. Identification of stage-specific defects and molecular pathways will not only yield signifi- 
cant mechanistic insights into the cellular basis for ineffective erythropoiesis but also help to design therapeutic strategies for improving clinical management of patients.

Despite the importance of studying erythropoiesis in a stage-specific manner, this has not been possible until recently. In the recent five years, great efforts have been made in developing novel methods for studying normal and abnormal erythropoiesis [28-31]. The development of these optimal methods and their applications are summarized in this review.

\section{Method for solation of murine erythroid progenitor BFU-E and CFU-E cells}

Traditionally, the erythroid progenitor BFU-E and CFU-E cells have been defined by colony assays [32-37]. With the aim to find small molecules that can stimulate erythropoiesis earlier than erythropoietin and enhance CFU-E production, Prof. Lodish's group [38] firstly established a method to purify erythroid progenitor cells from mouse E14.5-E15.5 fetal liver. Briefly, fetal liver cells were stained with biotin-conjugated antibodies against murine Ter119, B220, Mac-1, CD3 (cluster of differentiation 3), Gr-1, Sca-1, CD16/CD32, CD41 and CD34, then the biotin-negative fraction was stained with APC-CD117 (c-Kit) and FITC-CD71 (transferrin receptor) and within the $\mathrm{Kit}^{+}$ fraction, the level of CD71 expression was used to separate BFU-E (CD71 $\left.{ }^{10 \% \text { low }}\right)$ and CFU-E $\left(\mathrm{CD} 71^{20 \% \text { high }}\right)$. The purity of isolated BFU-E $\left(\mathrm{Kit}^{+} / \mathrm{CD} 71^{10 \% \text { low }}\right)$ and CFU-E $\left(\left(\mathrm{Kit}^{+} / \mathrm{CD} 71^{20 \% \text { high }}\right)\right.$ reached $90 \%$ [38]. The great advantage of this method is the ability to isolate pure BFU-E and CFU-E simultaneously. Using these cell populations, the authors identified compounds which promote BFU-E self-renewal [38].

\section{Method for isolation of murine erythroid precursors}

Erythroid precursors also refer to erythroblasts which include proerythroblasts, basophilic erythroblasts, polychromatic erythroblasts and orthochromatic erythroblasts. To identify the surface markers for isolating murine erythroblasts, we examined the changes in expression pattern of more than 30 red cell membrane proteins during murine terminal erythroid differentiation. All major transmembrane and skeletal proteins increased, while those of various adhesion molecules decreased. The adhesion molecule CD44 was found to exhibit a progressive and the most dramatic decrease with more than 30-fold during erythroid differentiation from murine proerythroblast to orthochromatic erythroblast. In contrast, the expression of CD71 which was widely used to separate different stages of murine erythroid cells did not show significant change. These results strongly suggest that CD44 might be a better surface marker than CD71 for isolating murine erythroblasts at distinct developmental stage. Indeed, use of TER119 (erythroid lineage marker), CD44 and forward scatter (FSC, cell size) enabled purification of murine erythroblasts at distinct stages of terminal erythroid differentiation [28]. In contrast, the use of CD71 resulted in the mixture of various stages of erythroblasts except for a pure population of proerythroblasts $[28,39]$.

\section{Method for quantification of murine terminal erythroid differentiation}

Under physiological condition, murine proerythroblast undergoes three mitoses to sequentially generate basophilic erythroblasts, polychromatic erythroblasts, and orthochromatic erythroblasts. Thus, it is presumed that during normal terminal erythroid differentiation, the ratio of Pro:Baso: Poly:Ortho should follow a $1: 2: 4: 8$ pattern. Liu et al. recently developed a new strategy to quantify this process in vivo [29]. Briefly, CD $45^{+}$cells from single cell suspension of normal murine bone marrow were firstly depleted by magnetic separation. Then the $\mathrm{CD}^{-} 5^{-}$cells were stained with different fluorescence conjugated antibodies, including TER119, CD44, CD45, CD11b, GR1 and the viability marker 7AAD, and analyzed by flow cytometry. Finally, the TER119, CD44 and FSC were used to gate different populations of terminally differentiated erythroid cell populations (Figure 1). This novel method not only enables successful in vivo quantitation of murine terminal erythroid differentiation, but also could clearly separate all murine terminally differentiating erythroid cells: Pro, Baso, Poly, Ortho erythroblasts, reticulocytes, and red blood cells. This novel method provided accurate means for studying erythroid differentiation and erythroid related disorders in mouse model [40-44]. Evaluating this achievement in a review, professor Palis said: this research created a novel method of realizing the separation of cell subsets through flow cytometry and the obtained cells can be used in the further research [45].

\section{Method for isolation of human erythroid progenitor BFU-E and CFU-E cells}

While considerable progress has been made in the study of murine erythropoiesis [38,46-48], the knowledge on human erythropoiesis is limited. To study the process of human erythropoiesis, it is important to be able to isolate human erythroid cells at distinct stages of development. To identify the surface markers for human BFU-E and CFU-E, Li et al. [31] systematically examined the expression of surface 

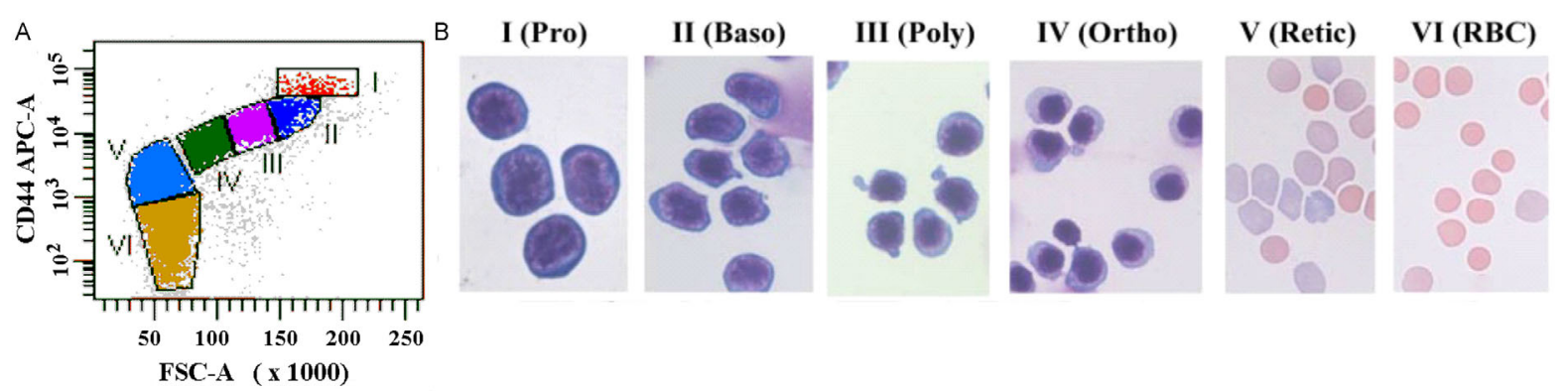

Figure 1 (color online) Flow cytometric analysis and isolation of erythroblasts of wild-type mice bone marrow cells. A, Representative erythropoiesis profiles of bone marrow: plot of CD44 vs FSC of the TER119 positive cells. B, Representative cytospin images $(\times 100)$ of the sorted populations gated in A. Adapted from our published work in [29].

markers (CD34, IL-3R, CD36, CD71, CD45 and GPA (glycophorin A) during early stage of human in vitro erythropoiesis. Based on the expression profiles of these surface markers and the related colony-forming ability, the surface markers of human BFU-E were identified as $\mathrm{CD} 45^{+} \mathrm{GPA}^{-}$ IL-3R ${ }^{-} \mathrm{CD} 34^{+}-\mathrm{CD} 36^{-} \mathrm{CD} 71^{\text {low }}$ and human CFU-E markers were identified as $\mathrm{CD} 45^{+} \mathrm{GPA}^{-} \mathrm{IL}-3 \mathrm{R}^{-} \mathrm{CD} 34^{-} \mathrm{CD} 36^{+}$ $\mathrm{CD} 71^{\text {high }}$. Combining with other lineage surface markers, this method can be used to isolate BFU-E and CFU-E from primary human samples such as human bone marrow, peripheral blood and umbilical cord blood [31]. The ability to isolate highly pure human BFU-E and CFU-E progenitors should enable detailed cellular and molecular characterization of these distinct progenitor populations and define the contribution of alterations in these progenitor populations to disordered erythropoiesis in various disorders.

\section{Method for quantification of human terminal erythroid differentiation}

We used similar approaches to identify surface markers for distinguishing human erythroid precursors (erythroblasts). For this, we examined the changes in the expression of 15 surface markers during terminal differentiation of in vitro human erythropoiesis. Different from mouse, the expression of CD44 did not decrease significantly. Instead, the expression of band 3 progressively increased and that of $\alpha 4$ integrin decreased. The use of GPA (erythroid lineage marker, equal to TER119 in the murine system), band 3 and $\alpha 4$ integrin as surface markers enabled us to develop a means to isolate highly purified populations of erythroblasts at each distinct stage from an erythroid culture system and from primary human bone marrow cells (Figure 2). Importantly, the ratio of erythroblasts at successive stage in the bone marrow followed the predicted $1: 2: 4: 8: 16$ pattern. In contrast, bone marrows from myelodysplastic syndrome patients exhibited altered terminal erythroid differentiation profiles [30]. Thus, our findings offer a means of isolating and quantifying each developmental stage during terminal erythropoiesis in vivo. Our findings should facilitate a comprehensive cellular and molecular characterization of each specific developmental stage of human erythroblasts and should provide a powerful means of identifying stage- specific defects in diseases associated with pathological erythropoiesis. Prof. Koury [49] stated in his review: the definition of erythrocytes belonging to distinct stages was only by means of morphology and Giemsa staining, but now isolateing and purifying erythrocytes of distinct stages is realized

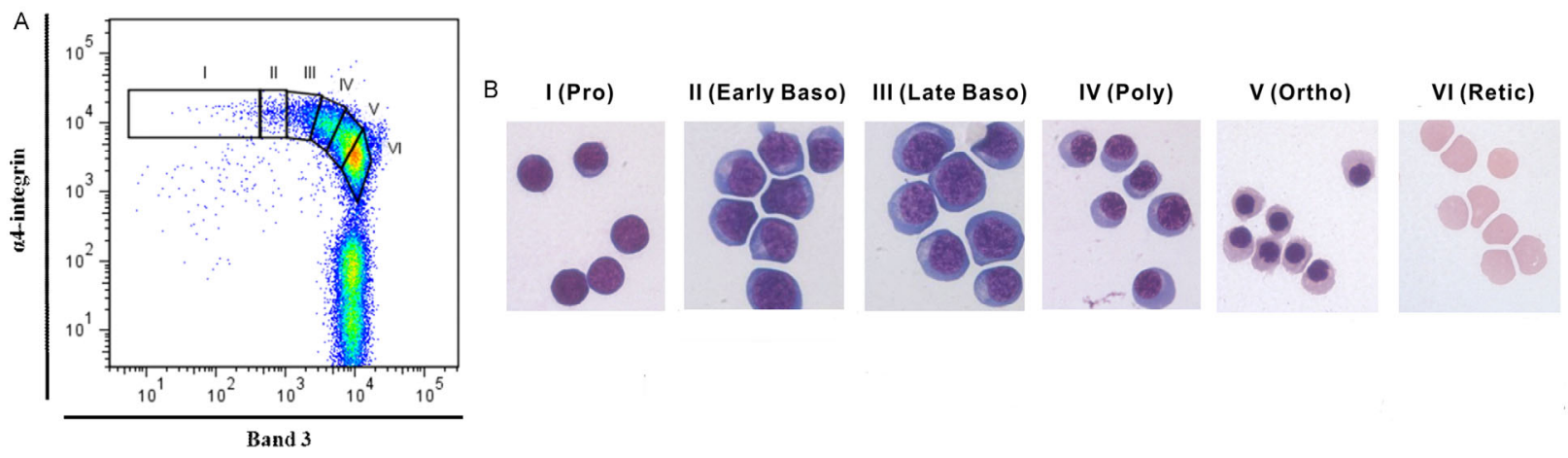

Figure 2 (color online) Flow cytometry analysis and sorting of primary human bone marrow erythroblasts. CD45 cells isolated from primary human bone marrow were stained with GPA, a4 integrin, and band 3. A, Plot of band 3 vs a4 integrin of the GPA positive cells. B, Representative cytospin images $(\times 100)$ of the sorted populations gated in A. Adapted from our published work in [30]. 
by combining surface markers and flow cytometry. This method offers novel strategies for quantitative research and diagnoses of human erythroid related disorders [50-52].

\section{Transcriptional profiles during both murine and human erythropoiesis}

As mentioned earlier, unlike most cell types, a distinguishing feature of erythropoiesis is that following each mitosis, the daughter cells are morphologically and functionally different from their parent cell. For example, major differences between BFU-E and CFU-E cells include different proliferative potential and dependence on erythropoietin [53,54]. Furthermore, during terminal erythroid differentiation, the ability to undergo cell division progressively diminishes. While proerythroblasts can divide four times, orthochromatic erythroblasts do not divide at all [30]. Structural and functional differences strongly suggest the differences in gene expression profiles. Global gene expression studies of human and murine erythroid development and differentiation have been previously performed [55-63]. However, in most studies, cells were not purified by cell surface or other markers, but were selected at differing time points in vivo or in culture. Moreover, most studies were performed using micro array analysis. To obtain the highest quality of transcriptome data, our laboratory has utilized the highly pure erythroid cells at each distinct developmental stage in conjunction with RNA-seq [31,64]. Our analysis uncovered the potential molecular regulation networks and revealed significant difference between human and mouse [64]. These data provide solid foundation for future studies of normal and disordered erythropoiesis.

\section{Changes in membrane protein during matu- ration of reticulocytes to erythrocytes}

Maturation of reticulocytes into mature erythrocytes is the last step of erythropoiesis. While it is well known that the transition of reticulocytes into erythrocytes is accompanied with dramatic changes in the structure and properties of the plasma membrane [65-69], the molecular changes were poorly understood. To address this, we compared the expression of more than 30 red cell membrane proteins between reticulocytes and erythrocytes. For the cytoskeleton proteins, we found that tubulin is lost; actin, tropomyosin, and myosin are dramatically decreased; and adducin is decreased a little, while the expression of spectrin, ankyrin, $4.1 \mathrm{R}, 4.2$, p55, tropomodulin, and 4.9, is not changed. For transmembrane proteins, we discover that CD71, GLUT4 (glucose transporter 4), Na/K-ATPase, and ICAM-4 (intercellular adhesion molecule-4) are largely decreased during reticulocyte maturation. GPA, CD47, Duffy, NHE1 (sodi- um/hydrogen exchanger 1), and Kell, are decreased slightly. However, band 3, Rh, RhAG (Rh-associated glycoprotein), GPC (glycophorin C), XK (X-Linked Kx Blood Group), are increased during reticulocyte maturation [70]. These findings laid the foundation for studying the structure and function of red cells [71,72], and offered strategies for examining red cell membrane proteins in various anemia models $[73,74]$.

\section{Conclusion}

Recent comprehensive characterization of membrane protein changes during erythropoiesis enabled the identification of optimal surface markers and established a series of method to distinguish erythroblasts at distinct stages of maturation both for human and murine. These novel methods enable the isolation of highly purified populations of erythroblasts at distinct stages and also offer a means of detection and diagnosis stage-specific defects in erythroid related diseases in inherited and acquired red cell disorders. The transcriptional profiles during erythropoiesis provide significant resource for further functional studies.

The author(s) declare that they have no conflict of interest.

This work was supported by grants from the National Natural Science Foundation of China (81470362, 81171905, 81272187).

1 Palis J. Ontogeny of erythropoiesis. Curr Opin Hematol, 2008, 15: 155-161

2 Finch CA, Sturgeon P. Erythrokinetics in cooley's anemia. Blood, 1957, 12: 64-73

3 Pootrakul P, Sirankapracha P, Sankote J, Kachintorn U, Maungsub W, Sriphen K, Thakernpol K, Atisuk K, Fucharoen S, Chantraluksri U, Shalev O, Hoffbrand AV. Clinical trial of deferiprone iron chelation therapy in beta-thalassaemia/haemoglobin E patients in thailand. Br J Haematol, 2003, 122: 305-310

4 Kean LS, Brown LE, Nichols JW, Mohandas N, Archer DR, Hsu LL. Comparison of mechanisms of anemia in mice with sickle cell disease and beta-thalassemia: peripheral destruction, ineffective erythropoiesis, and phospholipid scramblase-mediated phosphatidylserine exposure. Exp Hematol, 2002, 30: 394-402

5 Ginzburg Y, Rivella S. Beta-thalassemia: a model for elucidating the dynamic regulation of ineffective erythropoiesis and iron metabolism. Blood, 2011, 118: 4321-4330

6 Wickramasinghe SN, Wood WG. Advances in the understanding of the congenital dyserythropoietic anaemias. Br J Haematol, 2005, 131: 431-446

7 Heimpel H, Schwarz K, Ebnother M, Goede JS, Heydrich D, Kamp T, Plaumann L, Rath B, Roessler J, Schildknecht O, Schmid M, Wuillemin W, Einsiedler B, Leichtle R, Tamary H, Kohne E. Congenital dyserythropoietic anemia type I (CDA I): molecular genetics, clinical appearance, and prognosis based on long-term observation. Blood, 2006, 107: 334-340

8 Schwarz K, Iolascon A, Verissimo F, Trede NS, Horsley W, Chen W, Paw BH, Hopfner KP, Holzmann K, Russo R, Esposito MR, Spano D, De Falco L, Heinrich K, Joggerst B, Rojewski MT, Perrotta S, Denecke J, Pannicke U, Delaunay J, Pepperkok R, Heimpel H. Mutations affecting the secretory COPII coat component SEC23B cause 
congenital dyserythropoietic anemia type II. Nat Genet, 2009, 41: 936-940

9 Diamond LK, Wang WC, Alter BP. Congenital hypoplastic anemia. Adv Pediatr, 1976, 22: 349-378

10 Lipton JM, Ellis SR. Diamond-Blackfan anemia: diagnosis, treatment, and molecular pathogenesis. Hematol Oncol Clin North Am, 2009, 23: 261-282

11 Chang KH, Tam M, Stevenson MM. Inappropriately low reticulocytosis in severe malarial anemia correlates with suppression in the development of late erythroid precursors. Blood, 2004, 103: 3727-3735

12 Casals-Pascual C, Kai O, Cheung JO, Williams S, Lowe B, Nyanoti M, Williams TN, Maitland K, Molyneux M, Newton CR, Peshu N, Watt SM, Roberts DJ. Suppression of erythropoiesis in malarial anemia is associated with hemozoin in vitro and in vivo. Blood, 2006, 108: 2569-2577

13 Haldar K, Mohandas N. Malaria, erythrocytic infection, and anemia. Hematology, 2009, 87-93

14 Nimer SD. Myelodysplastic syndromes. Blood, 2008, 111: 4841-4851

15 List A, Dewald G, Bennett J, Giagounidis A, Raza A, Feldman E, Powell B, Greenberg P, Thomas D, Stone R, Reeder C, Wride K, Patin J, Schmidt M, Zeldis J, Knight R, Myelodysplastic Syndrome-003 Study I. Lenalidomide in the myelodysplastic syndrome with chromosome 5q deletion. N Engl J Med, 2006, 355: 1456-1465

16 Ebert BL, Galili N, Tamayo P, Bosco J, Mak R, Pretz J, Tanguturi S, Ladd-Acosta C, Stone R, Golub TR, Raza A. An erythroid differentiation signature predicts response to lenalidomide in myelodysplastic syndrome. PLoS Med, 2008, 5: e35

17 Lipton JM, Kudisch M, Gross R, Nathan DG. Defective erythroid progenitor differentiation system in congenital hypoplastic (Diamond-Blackfan) anemia. Blood, 1986, 67: 962-968

18 Bagnara GP, Zauli G, Vitale L, Rosito P, Vecchi V, Paolucci G, Avanzi GC, Ramenghi U, Timeus F, Gabutti V. In vitro growth and regulation of bone marrow enriched $\mathrm{CD} 34+$ hematopoietic progenitors in diamond-blackfan anemia. Blood, 1991, 78: 2203-2210

19 Dgany O, Avidan N, Delaunay J, Krasnov T, Shalmon L, Shalev H, Eidelitz-Markus T, Kapelushnik J, Cattan D, Pariente A, Tulliez M, Cretien A, Schischmanoff PO, Iolascon A, Fibach E, Koren A, Rossler J, Le Merrer M, Yaniv I, Zaizov R, Ben-Asher E, Olender T, Lancet D, Beckmann JS, Tamary H. Congenital dyserythropoietic anemia type $\mathrm{I}$ is caused by mutations in codanin-1. Am J Hum Genet, 2002, 71: 1467-1474

20 Arnaud L, Saison C, Helias V, Lucien N, Steschenko D, Giarratana MC, Prehu C, Foliguet B, Montout L, de Brevern AG, Francina A, Ripoche P, Fenneteau O, Da Costa L, Peyrard T, Coghlan G, Illum N, Birgens H, Tamary H, Iolascon A, Delaunay J, Tchernia G, Cartron JP. A dominant mutation in the gene encoding the erythroid transcription factor KLF1 causes a congenital dyserythropoietic anemia. Am J Hum Genet, 2010, 87: 721-727

21 Satchwell TJ, Pellegrin S, Bianchi P, Hawley BR, Gampel A, Mordue KE, Budnik A, Fermo E, Barcellini W, Stephens DJ, van den Akker E, Toye AM. Characteristic phenotypes associated with congenital dyserythropoietic anemia (type II) manifest at different stages of erythropoiesis. Haematologica, 2013, 98: 1788-1796

22 Liljeholm M, Irvine AF, Vikberg AL, Norberg A, Month S, Sandstrom H, Wahlin A, Mishima M, Golovleva I. Congenital dyserythropoietic anemia type III (CDA III) is caused by a mutation in kinesin family member, KIF23. Blood, 2013, 121: 4791-4799

23 Yuan J, Angelucci E, Lucarelli G, Aljurf M, Snyder LM, Kiefer CR, Ma L, Schrier SL. Accelerated programmed cell death (apoptosis) in erythroid precursors of patients with severe beta-thalassemia (cooley's anemia). Blood, 1993, 82: 374-377

24 Pootrakul P, Sirankapracha P, Hemsorach S, Moungsub W, Kumbunlue R, Piangitjagum A, Wasi P, Ma L, Schrier SL. A correlation of erythrokinetics, ineffective erythropoiesis, and erythroid precursor apoptosis in thai patients with thalassemia. Blood, 2000, 96: 2606-2612

25 Mathias LA, Fisher TC, Zeng L, Meiselman HJ, Weinberg KI, Hiti AL, Malik P. Ineffective erythropoiesis in beta-thalassemia major is due to apoptosis at the polychromatophilic normoblast stage. Exp Hematol, 2000, 28: 1343-1353

26 Pecci A, Travaglino E, Klersy C, Invernizzi R. Apoptosis in relation to CD34 antigen expression in normal and myelodysplastic bone marrow. Acta Haematol, 2003, 109: 29-34

27 Parker JE, Mufti GJ, Rasool F, Mijovic A, Devereux S, Pagliuca A. The role of apoptosis, proliferation, and the Bcl-2-related proteins in the myelodysplastic syndromes and acute myeloid leukemia secondary to MDS. Blood, 2000, 96: 3932-3938

28 Chen K, Liu J, Heck S, Chasis JA, An X, Mohandas N. Resolving the distinct stages in erythroid differentiation based on dynamic changes in membrane protein expression during erythropoiesis. Proc Natl Acad Sci USA, 2009, 106: 17413-17418

29 Liu J, Zhang J, Ginzburg Y, Li H, Xue F, De Franceschi L, Chasis JA, Mohandas N, An X. Quantitative analysis of murine terminal erythroid differentiation in vivo: novel method to study normal and disordered erythropoiesis. Blood, 2013, 121: e43-e49

30 Hu J, Liu J, Xue F, Halverson G, Reid M, Guo A, Chen L, Raza A, Galili N, Jaffray J, Lane J, Chasis JA, Taylor N, Mohandas N, An X. Isolation and functional characterization of human erythroblasts at distinct stages: implications for understanding of normal and disordered erythropoiesis in vivo. Blood, 2013, 121: 3246-3253

31 Li J, Hale J, Bhagia P, Xue F, Chen L, Jaffray J, Yan H, Lane J, Gallagher PG, Mohandas N, Liu J, An X. Isolation and transcriptome analyses of human erythroid progenitors: BFU-E and CFU-E. Blood, 2014, 124: 3636-3645

32 Stephenson JR, Axelrad AA, McLeod DL, Shreeve MM. Induction of colonies of hemoglobin-synthesizing cells by erythropoietin in vitro. Proc Natl Acad Sci USA, 1971, 68: 1542-1546

33 McLeod DL, Shreeve MM, Axelrad AA. Improved plasma culture system for production of erythrocytic colonies in vitro: quantitative assay method for CFU-E. Blood, 1974, 44: 517-534

34 Iscove NN, Sieber F, Winterhalter KH. Erythroid colony formation in cultures of mouse and human bone marrow: analysis of the requirement for erythropoietin by gel filtration and affinity chromatography on agarose-concanavalin A. J Cell Physiol, 1974, 83: 309-320

35 Moriyama Y, Fisher JW. Effects of testosterone and erythropoietin on erythroid colony formation in human bone marrow cultures. Blood, 1975, 45: 665-670

36 Gregory CJ, Eaves AC. Human marrow cells capable of erythropoietic differentiation in vitro: definition of three erythroid colony responses. Blood, 1977, 49: 855-864

37 Gregory CJ, Eaves AC. Three stages of erythropoietic progenitor cell differentiation distinguished by a number of physical and biologic properties. Blood, 1978, 51: 527-537

38 Flygare J, Rayon Estrada V, Shin C, Gupta S, Lodish HF. HIF1alpha synergizes with glucocorticoids to promote BFU-E progenitor self-renewal. Blood, 2011, 117: 3435-3444

39 Liu J, Mohandas N, An X. Membrane assembly during erythropoiesis. Curr Opin Hematol, 2011, 18: 133-138

40 Suragani RN, Cadena SM, Cawley SM, Sako D, Mitchell D, Li R, Davies MV, Alexander MJ, Devine M, Loveday KS, Underwood KW, Grinberg AV, Quisel JD, Chopra R, Pearsall RS, Seehra J, Kumar R. Transforming growth factor-beta superfamily ligand trap ACE-536 corrects anemia by promoting late-stage erythropoiesis. Nat Med, 2014, 20: 408-414

41 Pimentel H, Parra M, Gee S, Ghanem D, An X, Li J, Mohandas N, Pachter L, Conboy JG. A dynamic alternative splicing program regulates gene expression during terminal erythropoiesis. Nucleic Acids Res, 2014, 42: 4031-4042

42 Blanc L, Ciciotte SL, Gwynn B, Hildick-Smith GJ, Pierce EL, Soltis KA, Cooney JD, Paw BH, Peters LL. Critical function for the Ras-GTPase activating protein RASA3 in vertebrate erythropoiesis and megakaryopoiesis. Proc Natl Acad Sci USA, 2012, 109: 12099-12104

43 Watanabe S, De Zan T, Ishizaki T, Yasuda S, Kamijo H, Yamada D, Aoki T, Kiyonari H, Kaneko H, Shimizu R, Yamamoto M, Goshima G, Narumiya S. Loss of a Rho-regulated actin nucleator, mDia2, impairs cytokinesis during mouse fetal erythropoiesis. Cell Rep, 2013, 
5: 926-932

44 Stowell SR, Henry KL, Smith NH, Hudson KE, Halverson GR, Park JC, Bennett AM, Girard-Pierce KR, Arthur CM, Bunting ST, Zimring JC, Hendrickson JE. Alloantibodies to a paternally derived RBC KEL antigen lead to hemolytic disease of the fetus/newborn in a murine model. Blood, 2013, 122: 1494-1504

45 Palis J. Primitive and definitive erythropoiesis in mammals. Front Physiol, 2014, 5: 3

46 Heath DS, Axelrad AA, McLeod DL, Shreeve MM. Separation of the erythropoietin-responsive progenitors BFU-E and CFU-E in mouse bone marrow by unit gravity sedimentation. Blood, 1976, 47: 777-792

47 Terszowski G, Waskow C, Conradt P, Lenze D, Koenigsmann J, Carstanjen D, Horak I, Rodewald HR. Prospective isolation and global gene expression analysis of the erythrocyte colony-forming unit (CFU-E). Blood, 2005, 105: 1937-1945

48 Stumpf M, Waskow C, Krotschel M, van Essen D, Rodriguez P, Zhang X, Guyot B, Roeder RG, Borggrefe T. The mediator complex functions as a coactivator for GATA-1 in erythropoiesis via subunit MED1/TRAP220. Proc Natl Acad Sci USA, 2006, 103: 18504-18509

49 Koury MJ. Abnormal erythropoiesis and the pathophysiology of chronic anemia. Blood Rev, 2014, 28: 49-66

50 Arlet JB, Ribeil JA, Guillem F, Negre O, Hazoume A, Marcion G, Beuzard Y, Dussiot M, Moura IC, Demarest S, de Beauchene IC, Belaid-Choucair Z, Sevin M, Maciel TT, Auclair C, Leboulch P, Chretien S, Tchertanov L, Baudin-Creuza V, Seigneuric R, Fontenay M, Garrido C, Hermine O, Courtois G. Hsp70 sequestration by free alpha-globin promotes ineffective erythropoiesis in beta-thalassaemia. Nature, 2014, 514: 242-246

51 Ludwig LS, Gazda HT, Eng JC, Eichhorn SW, Thiru P, Ghazvinian R, George TI, Gotlib JR, Beggs AH, Sieff CA, Lodish HF, Lander ES, Sankaran VG. Altered translation of GATA1 in Diamond-Blackfan anemia. Nat Med, 2014, 20: 748-753

52 Bibikova E, Youn MY, Danilova N, Ono-Uruga Y, Konto-Ghiorghi Y, Ochoa R, Narla A, Glader B, Lin S, Sakamoto KM. Tnf-mediated inflammation represses GATA1 and activates p38 map kinase in RPS19-deficient hematopoietic progenitors. Blood, 2014, 124: 3791-3798

53 Dai CH, Krantz SB, Zsebo KM. Human burst-forming units-erythroid need direct interaction with stem cell factor for further development. Blood, 1991, 78: 2493-2497

54 Muta K, Krantz SB, Bondurant MC, Wickrema A. Distinct roles of erythropoietin, insulin-like growth factor I, and stem cell factor in the development of erythroid progenitor cells. J Clin Invest, 1994, 94: 34-43

55 Keller MA, Addya S, Vadigepalli R, Banini B, Delgrosso K, Huang $\mathrm{H}$, Surrey S. Transcriptional regulatory network analysis of developing human erythroid progenitors reveals patterns of coregulation and potential transcriptional regulators. Physiol Genomics, 2006, 28: 114-128

56 Merryweather-Clarke AT, Atzberger A, Soneji S, Gray N, Clark K, Waugh C, McGowan SJ, Taylor S, Nandi AK, Wood WG, Roberts DJ, Higgs DR, Buckle VJ, Robson KJ. Global gene expression analysis of human erythroid progenitors. Blood, 2011, 117: e96-e108

57 Gubin AN, Njoroge JM, Bouffard GG, Miller JL. Gene expression in proliferating human erythroid cells. Genomics, 1999, 59: 168-177

58 Singleton BK, Burton NM, Green C, Brady RL, Anstee DJ. Mutations in EKLF/KLF1 form the molecular basis of the rare blood group in(Lu) phenotype. Blood, 2008, 112: 2081-2088

59 Pilon AM, Arcasoy MO, Dressman HK, Vayda SE, Maksimova YD, Sangerman JI, Gallagher PG, Bodine DM. Failure of terminal erythroid differentiation in EKLF-deficient mice is associated with cell cycle perturbation and reduced expression of E2F2. Mol Cell Biol, 2008, 28: 7394-7401

60 Kingsley PD, Greenfest-Allen E, Frame JM, Bushnell TP, Malik J, McGrath KE, Stoeckert CJ, Palis J. Ontogeny of erythroid gene expression. Blood, 2013, 121: e5-e13

61 Isern J, He Z, Fraser ST, Nowotschin S, Ferrer-Vaquer A, Moore R, Hadjantonakis AK, Schulz V, Tuck D, Gallagher PG, Baron MH. Single-lineage transcriptome analysis reveals key regulatory pathways in primitive erythroid progenitors in the mouse embryo. Blood, 2011, 117: 4924-4934

62 Sripichai O, Kiefer CM, Bhanu NV, Tanno T, Noh SJ, Goh SH, Russell JE, Rognerud CL, Ou CN, Oneal PA, Meier ER, Gantt NM, Byrnes C, Lee YT, Dean A, Miller JL. Cytokine-mediated increases in fetal hemoglobin are associated with globin gene histone modification and transcription factor reprogramming. Blood, 2009, 114: 2299-2306

63 Peller S, Tabach Y, Rotschild M, Garach-Joshua O, Cohen Y, Goldfinger N, Rotter V. Identification of gene networks associated with erythroid differentiation. Blood Cells Mol Dis, 2009, 43: 74-80

64 An X, Schulz VP, Li J, Wu K, Liu J, Xue F, Hu J, Mohandas N, Gallagher PG. Global transcriptome analyses of human and murine terminal erythroid differentiation. Blood, 2014, 123: 3466-3477

65 Mel HC, Prenant M, Mohandas N. Reticulocyte motility and form: studies on maturation and classification. Blood, 1977, 49: 1001-1009

66 Come SE, Shohet SB, Robinson SH. Surface remodelling of reticulocytes produced in response to erythroid stress. Nat New Biol, 1972, 236: $157-158$

67 Chasis JA, Prenant M, Leung A, Mohandas N. Membrane assembly and remodeling during reticulocyte maturation. Blood, 1989, 74: 1112-1120

68 Waugh RE, Mantalaris A, Bauserman RG, Hwang WC, Wu JH. Membrane instability in late-stage erythropoiesis. Blood, 2001, 97: 1869-1875

69 Waugh RE, McKenney JB, Bauserman RG, Brooks DM, Valeri CR, Snyder LM. Surface area and volume changes during maturation of reticulocytes in the circulation of the baboon. J Lab Clin Med, 1997, 129: 527-535

70 Liu J, Guo X, Mohandas N, Chasis JA, An X. Membrane remodeling during reticulocyte maturation. Blood, 2010, 115: 2021-2027

71 Shi J, Kundrat L, Pishesha N, Bilate A, Theile C, Maruyama T, Dougan SK, Ploegh HL, Lodish HF. Engineered red blood cells as carriers for systemic delivery of a wide array of functional probes. Proc Natl Acad Sci USA, 2014, 111: 10131-10136

72 Hasegawa A, Shimizu R, Mohandas N, Yamamoto M. Mature erythrocyte membrane homeostasis is compromised by loss of the GATA1-FOG1 interaction. Blood, 2012, 119: 2615-2623

73 Moyer JD, Nowak RB, Kim NE, Larkin SK, Peters LL, Hartwig J, Kuypers FA, Fowler VM. Tropomodulin 1-null mice have a mild spherocytic elliptocytosis with appearance of tropomodulin 3 in red blood cells and disruption of the membrane skeleton. Blood, 2010, 116: 2590-2599

74 Satchwell TJ, Bell AJ, Pellegrin S, Kupzig S, Ridgwell K, Daniels G, Anstee DJ, van den Akker E, Toye AM. Critical band 3 multiprotein complex interactions establish early during human erythropoiesis. Blood, 2011, 118: 182-191

Open Access This article is distributed under the terms of the Creative Commons Attribution License which permits any use, distribution, and reproduction in any medium, provided the original author(s) and source are credited. 